\title{
BUSINESS INTELLIGENCE FRAMEWORK FOR PERFORMANCE MEASUREMENT IN HIGHER EDUCATION STUDY PROGRAMS
}

\author{
Dedi Trisnawarman', Muhammad Choirul Imam² \\ ${ }^{1}$ Information Systems, Universitas Tarumanagara \\ Email:dedit@fti.untar.ac.id \\ ${ }^{2}$ Information Systems, Universitas Tarumanagara \\ Email: muhammad.825190105@stu.untar.ac.id
}

Masuk: 11-08-2020, revisi: 06-09-2020, diterima untuk diterbitkan: 06-09-2020

\begin{abstract}
Business Intelligence (BI) is an online application and realtime, needed by large and modern organizations to increase competitive advantage in the global competitive environment. Higher Education (HE) is a current organization that houses excellent resources, with the number of students reaching up to tens of thousands, thus requiring an application that can be used as a tool to achieve the organization's business goals. This study aims to build a BI model and framework aimed at developing decision-making applications for measuring the business performance of HE. The method used in this research is the BI development method which is derived from the software engineering development method and adapted to the Study Program Accreditation Instrument (IAPS) 4.0. The case study used is the Information Systems Study Program at Tarumanagara University. The BI development methods are: Business Case Assessment, Enterprise Infrastructure Evaluation, Project Planning, Project Requirements, Data Analysis, Prototyping, Meta Data Analysis, Database Design, ETL Design, Meta Data Design, ETL Development, Application Development, Data Mining, Meta Data Repository Development, Implementation, Release Evaluation. The results of this study are a development stage model and framework that can be used to build BI applications for study program performance measurement.
\end{abstract}

Keywords: Business Intelligence Framework; Performance Measurement; Higher Education

\begin{abstract}
ABSTRAK
Business Intelligence (BI) adalah aplikasi daringdan terkini, dibutuhkan oleh organisasi besar dan modern untuk meningkatkan keunggulan kompetitif dalam persaingan global. Perguruan tinggi adalah organisasi saat ini yang memiliki sumber daya yang sangat baik, dengan jumlah mahasiswa mencapai puluhan ribu, sehingga membutuhkan aplikasi yang dapat digunakan sebagai alat untuk mencapai tujuan bisnis organisasi. Penelitian ini bertujuan untuk membangun model dan framework BI yang bertujuan untuk mengembangkan aplikasi pengambilan keputusan untuk mengukur kinerja bisnis PT. Metode yang digunakan dalam penelitian ini adalah metode pengembangan BI yang bersumber dari metode pengembangan rekayasa perangkat lunak dan disesuaikan dengan Instrumen Akreditasi Program Studi (IAPS) 4.0. Studi kasus yang digunakan adalah Program Studi Sistem Informasi Universitas Tarumanagara. Metode pengembangan BI adalah: Business Case Assessment, Enterprise Infrastructure Evaluation, Project Planning, Project Requirements, Data Analysis, Prototyping, Metadata Analysis, Database Design, ETL Design, Metadata Design, ETL Development, Application Development, Data Mining, Metadata Pengembangan Repositori, Implementasi, Evaluasi Rilis. Hasil dari penelitian ini berupa model tahapan pengembangan dan kerangka kerja yang dapat digunakan untuk membangun aplikasi BI untuk pengukuran kinerja program studi.
\end{abstract}

Kata Kunci: Kerangka kerja Business Intelligence; Pengukuran Performa; Perguruan Tinggi 


\section{INTRODUCTION}

Education has been recognized as the most important strategy in every country in the world, and the efficiency and effectiveness of education management is the main target. Therefore it is necessary to measure performance to achieve these objectives (Kleesuwan, 2010).

In an effort to continuously improve quality, each institution of Higher Education (HE) must plan all of its development efforts based on self-evaluation, which is carried out comprehensively, structured and systematic. Self-evaluation must be used to better understand the current condition and quality of the institution to be used as the foundation of the institution to determine the desired conditions and qualities in the future. In management, evaluation is a crucial stage in developing a development program. Therefore, how to conduct a comprehensive, structured and systematic evaluation must be understood correctly, so that the results can be used as a basis for the planning process to achieve the desired goals of continuous quality improvement. The ability to carry out evaluations is an important factor in improving the quality of institutions. Evaluation is not merely aimed at proving performance but rather an effort to improve institutional performance. Therefore some of the benefits of self-evaluation include: get a picture of the real condition of the institution; as a foundation to fix the weaknesses of the institution; as a foundation for designing institutional development programs (BAN-PT 592018).

The performance measurement of HE can be done through accreditation instruments that have been standardized by the government or BAN-PT. BAN-PT develops accreditation instruments that are relevant to the development of the higher education sector in Indonesia and follows global developments. BAN-PT developed the Study Program Accreditation Instrument (IAPS) version 2018, which was briefly written by IAPS 4.0. Significant changes to IAPS 4.0, using nine criteria, namely: Vision, Mission, Objectives and Strategy, Civil Service, Governance and Cooperation, Students, Human Resources, Finance, Facilities and Infrastructure, Education, Research, Community Service, Outcomes and Achievements Tridharma (BAN-PT 59-2018).

IAPS 4.0 is oriented towards outputs and outcomes. IAPS 4.0 consists of a Self Evaluation Report and Academic Performance Report. Self Evaluation Report which describes the status and performance analysis of each criterion. The study program management unit is expected to be able to identify its strengths and aspects that need to be improved in the proposed study program accreditation.

The development of information technology and science, especially in the field of computing, enables rapid progress in making applications as a tool for decision making. Business Intelligence (BI) is an application that is online and realtime, needed by large and modern organizations in order to increase competitive advantage in a globally competitive environment. HE is a modern organization that houses large resources, with the number of students reaching up to tens of thousands, thus requiring an application that can be used as a tool to achieve the organization's business goals. Based on the description that has been explained, this research needs to be done. 
All universities in Indonesia are required to carry out accreditation, which is a measure of performance. BI is an application that can be used to assist data collection and analysis of decision making in performance measurement. The main contribution of this research is to produce a decision-making model and BI framework that can be used to measure the performance of universities in Indonesia.

In Scholtz et al. (2018), succeeded in building a Business Intelligence (BI) framework for managing sustainable information in HE, a method used based on HE case studies in South Africa. The BI sustainable tool is a solution that integrates data from various fields of sustainability and provides a single integrated view of information to stakeholders. This information is provided through a performance dashboard, which offers predictive capabilities to enable management to report sustainability and determine whether the agency meets its strategic objectives. The lessons learned can also help other universities to consider implementing BI for sustainability reporting. Evaluation results show that the use of BI tools is considered positive and that the framework can help overcome the obstacles HE faces in managing sustainability information effectively.

BI can be successfully implemented and effectively used in higher education, is an intelligent decision that will increase student success (Mutanga, 2015), (Guster, 2012). In Beckett, et.al. (2012), many institutions of higher education still have administrative information systems for students, finance, human resources and usually find it expensive to provide data for decision making. The reason is that most operational information systems for HEs are transactional because they process transactions rather than provide information (Guster, 2012).

In Henderi and Winarko (Henderi, 2013), conducted research to build a BI framework design for high schools. The BI framework design is carried out through stages: identifying the information needed, compiling key performance indicators (KPI), identifying data sources, the process of transformation and data analysis, and creating a framework design. Based on the results of the analysis and discussion, it was concluded that the BI high school framework is a unified system that functions to record, consolidate and analyze data, access, and deliver dashboard information to end-users. It is also known that high school BI frameworks consist of: data recording applications, primary data sources, data warehouses, data transformation and analysis, delivering information, and providing tools to access information.

BI theory is a general term that refers to the skills, processes, technology, applications and practices used to utilize an organization's internal and external information assets to support and enhance decision-making activities (Lock, 2011), (Imhoff, 2010). BI solutions in higher education have gained momentum, and according to (Guster, 2012) and (Imhoff, 2010) other than one-third of British, Higher Education institutions use IBM Cognos and even more institutions adopt Business Intelligence Solutions. The BI solution gives managers visibility into institutional processes, forecasts of the future behaviour of institutional processes and the ability to take proactive action in areas where their organization must improve its performance [8]. BI 
can be considered as a driver for Information Management Systems, and in the higher education sector, they present an opportunity to provide meaningful information about performance.

\section{METHODS}

The methodology used is based on the approach of software engineering development methods (Moss, 2003), as shown in Figure 1, namely justification, planning, Business Analysis, Design, Construction, Deployment.

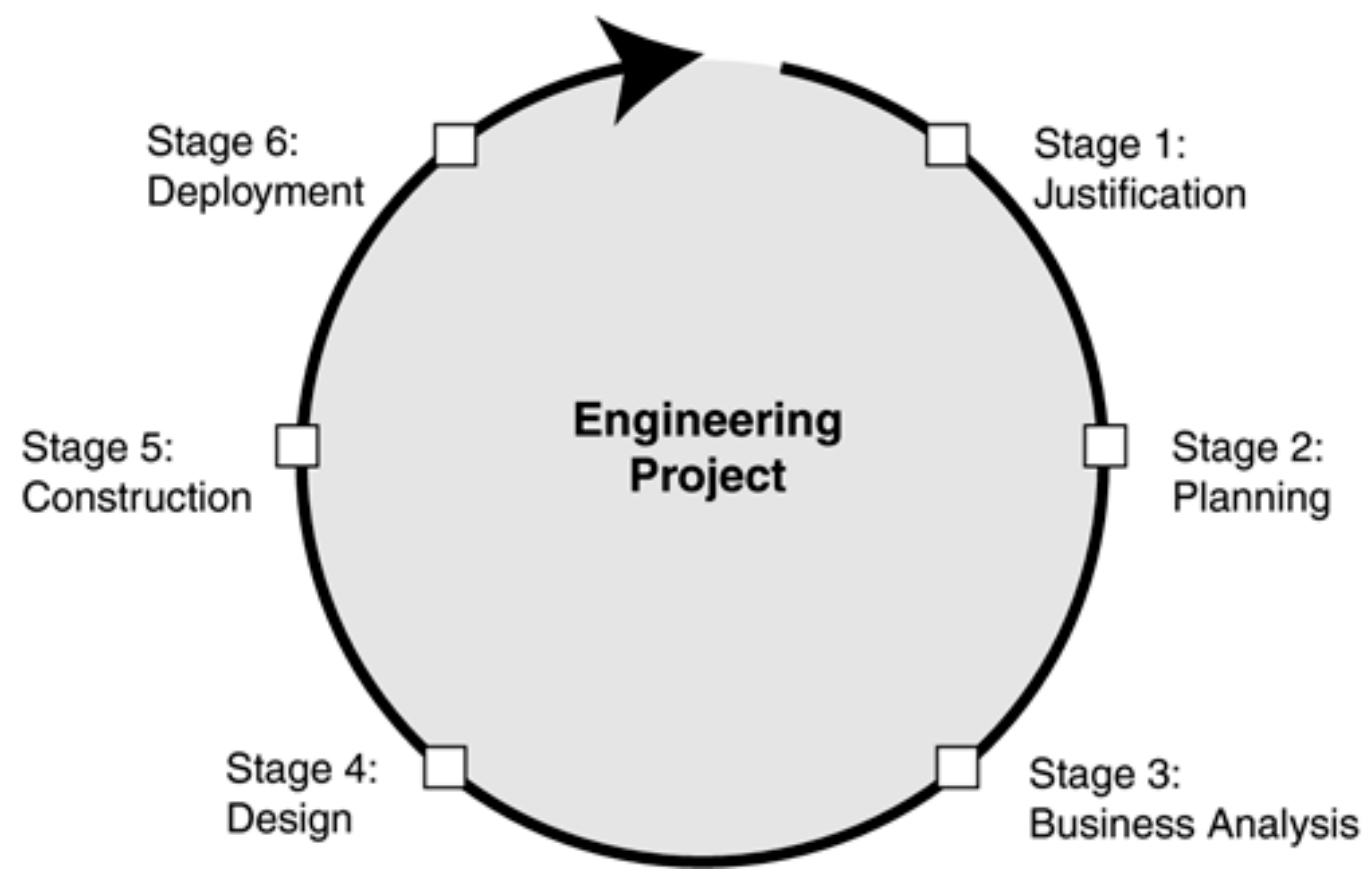

Figure 1. Software engineering method

Source: Authors, 2019

Furthermore, the process carried out refers to the framework of the preparation of self-evaluation based on IAPS 4.0, consisting of internal and external environments. The internal environment consists of nine criteria, and the external environment is divided into two parts namely;

a. Macro external environment; politics, economy, policy, social, culture, science and technology development.

b. Micro external environment; competitors, graduate users, prospective student sources, prospective lecturer sources, educational resources, eLearning, distance education, Open Course Ware (OCW), industry and community business needs, partners, and alliances.

The process of data collection is the initial process carried out to identify all the needs needed in building a model, the method used is a part of the fact-finding technique (FFT)(Connolly, 2010 ), namely field observations, interviews and questionnaires. Resource persons are stakeholders involved in the HE business process, such as lecturers, students, employees, parents of students, 
alumni and users of graduates. In addition, secondary data obtained from HE documents and relevant research results are also used.

\section{RESULT AND DISCUSSION}

The developed BI Framework aims to facilitate the development of BI applications. IAPS BI Framework 4.0 can be seen as in Figure 2. The proposed BI Framework consists of five parts, namely data source, collection, storing, analysis and reporting.

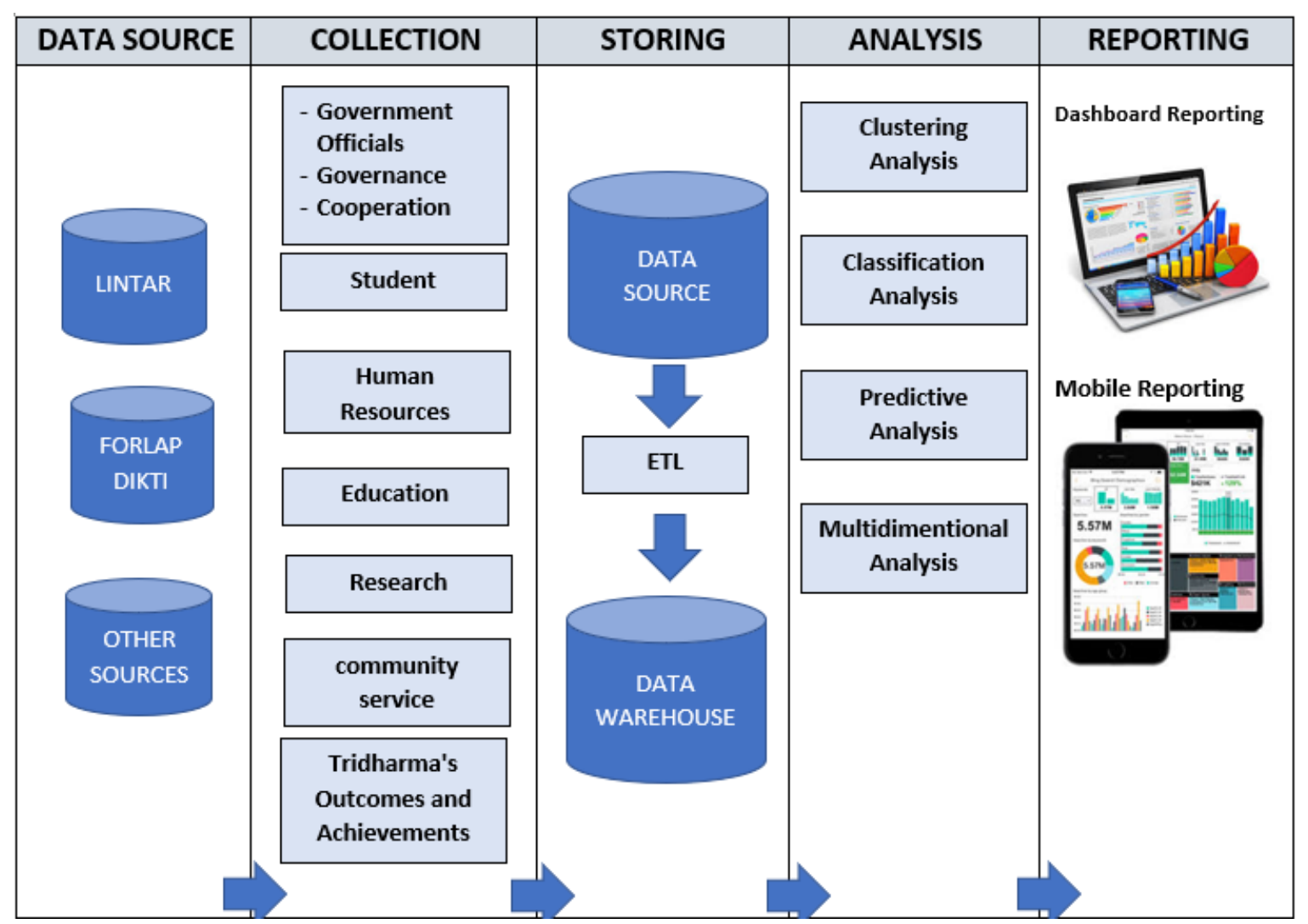

Figure 2. BI-IAPS Framework 4.0

Source: Authors, 2019

An explanation of the five parts in Figure 2 is as follows:

a. Data Source: BI data sources come from various operational database sources, Forlap Dikti, and other relevant sources. In the case of this study, HE's main data source comes from the Tarumanagara University Integrated Information Services operational database (LINTAR). The LINTAR database includes, among others, attendance, lectures, research, community service, publications, libraries, online guidance for academic advisors, lecturer administration, employee administration, student administration, final assignment hearings, student creativity programs. Besides, other important data sources are sources of data from the Ristekdikti higher education reporting database which can be accessed via the website https://forlap.ristekdikti.go.id/, as well as other supporting sources. 
b. Collection: Collection is the collection process obtained from the data source. The data collection process is grouped based on the organization's key performance indicators (KPI). KPI submitted based on the reference in IAPS 4.0 criteria set by Ristekdikti.

c. Storing: Storing is a continuation of the data collection process. After the KPI has been determined, the next step is to extract the data, transform it in an appropriate form and load it to be stored in the data warehouse. The storing process goes through three stages, known as the ETL process.

d. Analysis: The proposed analysis can be divided into two groups, namely the analysis produced using data mining methods, namely classification analysis, clustering analysis and predictive analysis. Next is the display analysis in the form of visualization analysis and multi-dimensional analysis. Visualization analysis is an analysis based on the appearance of graphs, maps, tables and other symbols that can make it easier to understand the information displayed. The multi-dimensional analysis is the appearance of analysis in the form of many dimensions or subjects that can be interconnected, such as location, time, event, number, and so on.

e. Reporting: Reporting included here is a form of reporting that can facilitate access to reporting and is easily understood. Available reporting forms are reporting in the form of a dashboard and can be accessed by car or mobile reporting.

\section{CONCLUSION AND RECOMMENDATION}

This research produces a roadmap for developing BI to measure the performance of the Study Program, by combining internal HE data with external data from HE stakeholders. This study also produced a BI framework for measuring the performance of the Study Program. The resulting framework consists of three main parts, namely: data source, data warehouse, and reporting analysis. The Framework and Roadmap generated from this research can assist in the development of BI applications for measuring the performance of the Study Program.

\section{REFERENCE}

BAN-PT. Appendix BAN-PT Regulation Number 59 of 2018 Concerning Guidelines for Preparation of Self Evaluation Reports, Guidelines for Preparation of Higher Education Performance Reports, and Assessment Matrices in Higher Education Accreditation Instruments

Beckett, T. \& McComb, B.E. (2012). Increase Enrollment, Retention and Student Sucess: Best Practices for Information Delivery and Strategic Alignment. WeFocus. Ed., New York: Information Builders, pp.1-34.

Connolly, T. \& Begg, C. (2010). Database Systems: a practical approach to design, implementation, and management. Pearson. Education.

Guster, D. \& Brown, C.G. (2012) The Application of Business Intelligence to Higher Education: Technical and Managerial Perspectives. Journal of Information Technology Management, 23(2), pp.42-62.

Henderi. \& Winarko, E. (2013). The Design of Business Intelligence Framework in Higher Education, National Mathematics Seminar and Its Applications

Imhoff, C. \& White, C. (2010). Business intelligence and collaboration: A natural marriage. Business Intelligence Journal, 15(3), pp.44-48. 
Kleesuwan, S., Mitatha, S., Yupapin, P.P. \& Piyatamrong, B. (2010). Business Intelligence in Thailand's Higher Educational Resources Management. Procedia-Social and Behavioral Sciences, 2(1), pp.8487.

Lock, M. (2011) Business Intelligence on TCO Diet: Slashing the Cost of Insight with Analytical Fitness. Aberdeen Group

Moss, L.T. \& Atre, S. (2003). Business intelligence roadmap: the complete project lifecycle for decisionsupport applications. Addison-Wesley Professional.

Mutanga, A. (2015). A Context-Based Business Intelligence Solution for South African Higher Education. Journal of Industrial and Intelligent Information, 3(2).

Scholtz, B., Calitz, A., \& Haupt, R. (2018). A Business Intelligence Framework for Sustainability Information Management in Higher Education. International Journal of Sustainability in Higher Education, 19(2), 266-290.

Sharman, D. (2010). An Introduction to Business Intelligence for Higher Education. Collegiate Project Services, pp.1-7. 
